\title{
On the Meaning and Use of Excellence in the Operations Literature: A Systematic Review
}

\author{
Matthias Thürer (corresponding author), Ivan Tomašević, Mark Stevenson, Lawrence D. \\ Fredendall and Charles W. Protzman
}

\begin{tabular}{|c|c|}
\hline Name: & Professor Matthias Thürer \\
\hline Institution: & Jinan University \\
\hline \multirow[t]{2}{*}{ Address: } & Institute of Physical Internet \\
\hline & $\begin{array}{l}\text { School of Electrical and Information Engineering } \\
519070 \text {, Zhuhai, PR China }\end{array}$ \\
\hline E-mail: & matthiasthurer@workloadcontrol.com \\
\hline Name: & Ivan Tomašević \\
\hline Institution: & University of Belgrade \\
\hline \multirow[t]{3}{*}{ Address: } & Faculty of Organizational Sciences \\
\hline & Jove Ilica 154 \\
\hline & $\begin{array}{l}\text { Belgrade, Serbia, } \\
\text { tomasevici@fon.bg.ac.rs }\end{array}$ \\
\hline Name: & Professor Mark Stevenson \\
\hline Institution: & Lancaster University \\
\hline \multirow[t]{4}{*}{ Address: } & Department of Management Science \\
\hline & Lancaster University Management School \\
\hline & Lancaster University \\
\hline & LA1 4YX - U.K. \\
\hline E-mail: & m.stevenson@lancaster.ac.uk \\
\hline Name: & Professor Lawrence D. Fredendall \\
\hline Institution: & Clemson University \\
\hline \multirow[t]{3}{*}{ Address: } & Department of Management \\
\hline & 101 Sirrine Hall \\
\hline & Clemson SC - United States \\
\hline Email: & flawren@clemson.edu \\
\hline Name: & Charles W. Protzman, MBA, CPM \\
\hline Institution: & BIG - Business Improvement Group LLC. \\
\hline Address: & 1403 Midmeadow Road \\
\hline & Towson, MD 21286, USA \\
\hline Email: & charlieprotzman@biglean.com \\
\hline
\end{tabular}

Keywords: Business Excellence; Operational Excellence; Service Excellence; Systematic Literature Review. 


\title{
On the Meaning and Use of Excellence in the Operations Literature: A Systematic Review
}

\begin{abstract}
Excellence is a term/concept that is widely used in research and practice. Yet although there have been many suggested definitions of excellence and the success factors behind excellence, few organizations have been able to achieve the goal of excellence. It has been argued that this is due to a genuine confusion amongst managers on what excellence means for their business. Using a systematic review of the operations literature on excellence concepts, we identify a plethora of concepts associated with excellence. In response, an overarching definition that seeks to consolidate the different concepts is presented. Excellence is defined as a combination of operational excellence (efficiency) and service excellence (effectiveness). Further analysis warrants that existing business excellence models may be detrimental to sustaining excellence and making good business. More specifically, business excellence models appear to overemphasize the creation of value whilst underemphasizing means of capturing this value. Moreover, they often lack a strategic component, including concepts such as strategic choice, alignment and sustained competitive advantage. This has major implications for research and practice.
\end{abstract}

Keywords: Business Excellence; Operational Excellence; Service Excellence; Systematic Literature Review. 


\section{Introduction}

This paper explores the meaning and use of the term "excellence" in the operations literature. It seeks to further our understanding of excellence based on the perception of excellence within the research community. Excellence is a concept that is widely used in research and practice. For example, in terms of research, there are journals such as Total Quality Management \& Business Excellence and Measuring Business Excellence. In terms of practice, there exist the Shingo Model for operational excellence (Chakravorty et al., 2008), the Deming Prize, the Baldrige performance excellence program, the European Foundation for Quality Management Excellence Model, and about 80 other national awards that largely base their framework on the latter two models (Grigg \& Mann, 2008; Mohammad et al., 2011; Talwar, 2011; Dahlgaard et al. 2013). These excellence models provide standard frameworks for inter- and intra-industry comparison in the context of best practices and benchmarking (Hermel \& Ramis-Pujol, 2003). If a process of continuous improvement is to be sustained and/or its pace increased, it is essential that an organization monitors performance using an appropriate performance measurement system. This system is provided by excellence models (Ritchie \& Dale, 2000), which provide the basis for measuring management and performance (Bowerman, 2002).

Hermel \& Ramis-Pujol (2003) see excellence through two lenses: results-driven and activity-centered. The first is the purpose of excellence; the second is the way to achieve excellence. Similarly, within the companies studied in Ritchie \& Dale (2000), business excellence is perceived as either being a measure of 'how good we are' or a means by which 'business can move forward'. This leads to the tasks of defining excellence and guiding excellence (Hermel \& Ramis-Pujol, 2003). However, although there have been many suggestions for a definition of excellence and the success factors behind excellence, only a few organizations have been able to achieve the goal - most likely because management does not have a profound understanding of what it really means to be excellent (Dahlgaard-Park \& Dahlgaard, 2007). Indeed, there are still some important gaps in our understanding of what really is excellence (Lu et al., 2011). Ritchie \& Dale (2000) even argue that there appears to be genuine confusion in practice as to what excellence is and what it can do for an organization. Similarly, Hermel \& Ramis-Pujol (2003) argue that managers seem to have difficulty understanding management concepts such as excellence. In response, a first objective of our study is to clarify and define business excellence. We will track the history of excellence in the operations literature and summarize definitions from the literature to capture author perceptions of excellence. It is hoped that this will provide an important 
reference framework that dispels the confusion surrounding the term excellence both in research and practice.

Based on findings from the literature, Dahlgaard et al. (2013) argue that investing in excellence 'pays'. However, many of America's best-run companies, which gave rise to the excellence concept in Peters \& Waterman (1982), became unsuccessful (Caruana et al. 1995; Dahlgaard-Park \& Dahlgaard, 2007). Similarly, Hughes \& Halsall (2002) argue that the use of an excellence model by itself may not remove fundamental barriers to improvement. The question remains: How can excellence be sustained? Exploring this question is the second and final objective of our study. The vehicle to address our two objectives is a systematic review of the literature.

The remainder of this paper is organized as follows. Section 2 presents the methodology behind our systematic review of the literature on the use and meaning of business excellence. Major excellence concepts/models from the literature are then identified in Section 3 before definitions of excellence from the literature are presented and discussed in Section 4. An overall discussion of results is then provided in Section 5, leading to a definition and critical discussion of business excellence. Final conclusions are summarized in Section 6, where managerial implications and future research directions are also outlined.

\section{Methodology - Systematic Review of the Literature}

This paper starts with the following two research questions:

1. How is excellence defined in the operations literature?

2. How can excellence be sustained?

A review of the literature has been conducted to answer these two questions. A systematic procedure for retrieving and selecting the articles (following Tranfield et al. (2003)) has been used to refrain from judgements on the value of a study. The three subsections below outline the approach adopted for sourcing, screening, and analyzing the articles (subsections 2.1 to 2.3) before the sample characteristics are summarized in Section 2.4. Meanwhile, the overall scheme is illustrated in Figure 1.

It should be noted that there have been recent literature reviews on Quality and Business Excellence. For example, Dereli et al. (2011) and Lo \& Chai (2012) reviewed the literature published in Total Quality Management \& Business Excellence while Dahlgaard-Park et al. (2013) extended the analysis, reviewing studies on quality and business excellence that can be found in the ABI/INFORM complete periodical database. However, these reviews adopt a 
quantitative approach, focusing on the origins of authors, keywords, and a citation analysis. In contrast, our analysis focuses on the meaning of business excellence and, consequently, is qualitative, based on content analysis.

\section{[Take in Figure 1]}

\subsection{Sourcing the Articles}

The bibliographic database used for sourcing the articles was Scopus - due to its large coverage, e.g. compared to Web of Science, and its accuracy in terms of citation counts, e.g. compared to Google Scholar. We recognize that there is an extensive literature in the form of books and white papers; however, it was not possible for us to have access to all relevant books for a systematic review. Our search has been further restricted to articles from peerreviewed journals to ensure the quality of the sources held in our database. Scopus was queried in June, 2016 using the terms: 'business excellence', 'manufacturing excellence', 'operational excellence', 'operations excellence', 'production excellence' and 'service excellence'. To keep our results to a reasonable number, we restricted our search to the title, abstract, and keywords of papers while the subject area was limited to 'business, management and accounting', 'engineering', 'decision sciences', 'computer science', 'economics, econometric and finance', and 'multidisciplinary'. Document type was limited to 'articles' and 'articles in press'. There was no restriction on the year of publication.

We retrieved for 'business excellence', 478 entries; 'manufacturing excellence', 88 entries; 'operational excellence', 198 entries; 'operations excellence', 15 entries; 'production excellence', 5 entries; and 'service excellence', 128 entries. In total, this process retrieved 912 articles.

\subsection{Screening the Articles}

The original sample of 912 articles was reduced to 858 by removing duplicates. This was further reduced to 853 articles by excluding apparently unrelated articles. The sample of 853 articles was further reduced based on citation counts. We decided to limit our final sample to papers that had been cited 2 times or more, with the cut-off point of 2 citations set arbitrarily. Thus, all articles with 1 or no citations were removed from the sample, leaving 474 articles. Since this cut-off point would be unfair for recently published articles, we included articles with less than 2 citations if they were published in 2015 or 2016. This added another 79 articles to our review. The sample therefore consisted of 553 articles. Using several channels for retrieving the full articles, a total of 470 articles could be obtained. During this article 
retrieval and screening process, we discovered that a further 46 articles in the sample were not in fact sufficiently related to our study. For example, if Winner of a Business Excellence Award were used for building the sample of a survey but no further use of business excellence was made, or if the term 'business excellence' was just used as a keyword. The final sample of analyzed full papers was thus $470-43=427$ articles.

Finally, note that only the articles that are referred to directly in our review (or tables) are listed in the references at the end of this paper, but a full reference list of all 427 articles is available from the corresponding author upon request.

\subsection{Analyzing the Articles}

This stage involved extracting and documenting information from each of the 427 sources. To minimize subjectivity, the authors: (i) cross-checked results; and, (ii) conducted regular meetings to resolve any emerging inconsistencies in interpreting the results. Our major research vehicle was content analysis, since we sought to explore the meaning and use of the term 'excellence' in the operations literature. Our analysis focused on two main aspects, with the results presented in the next section:

i. The given definition of excellence (if any); and

ii. The use of the term excellence in the text - since it is this context of use that allows meaning to be distilled from texts (Krippendorff, 2003).

As a template for data collection, a simple matrix was used where, for each paper (row), we asked (column): What excellence concept is used - business excellence, operational excellence, etc.? What is the formal definition of this excellence concept (if given)? What is the context of use (i.e. what is it used for)? What would be its definition out of its context of use? Is it related to efficiencies or to effectiveness? Does excellence mean doing good business? With which concept is it used (Lean, Total Quality Management, etc.)? For what is it used in this concept (e.g. performance measurement, quality award, etc.)? Is the paper on services, manufacturing, etc.? What is the methodology used in the work?

Before presenting the results of the above analysis process, Section 2.4 summarizes the basic sample characteristics.

\subsection{Sample Characteristics}

Basic sample characteristics for the 427 articles are summarized in tables 1, 2, and 3. Table 1 presents the distribution of journals where the articles have been published. Our sample contains a broad set of different journals. As expected, leading Quality Management journals 
feature heavily in Table 1. This supports the claim that the review is representative of the literature and gives support to the argument that excellence is linked to the quality movement. This argument is further supported by Table 2, which presents the distribution of the main management concepts mentioned together with excellence in the texts. Meanwhile, Table 3 summarizes the areas of application. We can see that excellence pervaded all possible areas of application.

[Take in Table 1, Table 2, \& Table 3]

Finally, the distribution of the articles by year of publication is shown in Figure 2. This indicates that the highest number of articles on excellence was published in 2008. This high number of articles in 2008 coincides with the sample characteristics in Dahlgaard-Park et al. (2013). However, we could not observe the high number of publications around 2003 observed in Dahlgaard-Park et al. (2013), which may be due to our cut-off point or differences in search strategy. The increase for 2015 and 2016 is due to the fact that a minimum citation count of 2 or more was not enforced for these most recent years in our study. Other measures, like the distribution of articles per country, author profiles, etc. did not appear relevant to us and are thus not presented here.

\section{[Take in Figure 2]}

\section{Results - Excellence Concepts/Models}

This section presents a discussion of excellence concepts/models from the literature. Section 3.1 discusses excellence in the context of Total Quality Management (TQM) and Quality Award Models before excellence in the context of the Toyota Production System and Lean Management is discussed in Section 3.2. Alternative excellence models are then discussed in Section 3.3. A short summary discussion is presented in Section 3.4.

\subsection{Total Quality Management (TQM) and International Quality Award Models}

Excellence models are strongly related to quality since quality prizes were founded or established to recognize the organizations that excelled in the implementation of quality practice (Hermel \& Ramis-Pujol, 2003). In fact, business excellence is often seen as synonymous with TQM or as an extension of TQM (Oakland \& Tanner, 2008; DahlgaardPark, 2011, 2013).

Arguably the first Quality Award was established by the Japanese Union of Scientists and Engineers in 1951 to honor W.E. Deming: The Deming Prize. In an effort to improve quality 
management practices and the competitiveness of US firms, the Malcolm Baldrige National Quality Improvement Act was signed in 1987, with the first Malcolm Baldrige National Quality Award (MBNQA) being awarded in 1988. In the same year, 1988, 14 major European companies formed the European Foundation of Quality Management. One major motivating factor this movement was survey evidence that the quality of Japanese products was superior to US products, which in turn was superior to European products (Dale et al., 2000). By 1991, the European Foundation of Quality Management (EFQM) developed the European Quality Award (EQA) program - now referred to as the EFQM award - to honor outstanding European businesses.

Grigg \& Mann (2008) estimate that over 80 nations administer a national Quality Award or Business Excellence Model; around 50 use the MBNQA criteria; and a further 25 have adopted the EFQMA criteria. The remaining models are tailored to suit particular business contexts, for example in Australia, Malaysia, Singapore, Japan, Mexico, Brazil, South Africa, and Canada. In a more recent study, Talwar (2011) reports on there being more than 100 Business Excellence Models/National Quality Awards in 82 countries. A more detailed listing of 97 awards can be found in Mohammad et al. (2011).

Most of these models are based on the Deming Prize, MBNQA, or EFQMA. While the Deming Prize and the MBNQA have a strong link to the nation of their origin - Japan and the US, respectively - the case for the EFQMA is different. The EFQM that is behind the EFQMA was founded by business organizations. While most countries of the European Union follow the EFQMA criteria or adopt a substantial part of it for their national quality award, there are some exceptions. For example, the Irish and Swedish national quality awards are based on the MBNQA while the Hungarian national quality award follows the Deming Prize (Mavroidis et al., 2007).

\subsubsection{Evaluation Criteria}

Although there are some differences between the three models - the Deming Prize, MBNQA, and EFQMA - they have a number of common elements (Ritchie \& Dale, 2000). According to Dahlgaard-Park \& Dahlgaard (2007), there are nine EFQMA criteria. Five criteria are enablers: leadership; people management; policy and strategy; partnerships and resources; and, processes. Meanwhile, four criteria are results: people results; customer results; society results; and, key performance results. The excellence model is based on the premise that excellence in terms of the results is achieved through excellence in terms of the enablers (Bowerman, 2002). Similar criteria are used for the MBNQA but with less detail on the 
results. The seven critical aspects for managing an organization and performing as an organization are: leadership; strategy; customers; measurement, analysis, and knowledge management; workforce; operations; and, results. In contrast to MBNQA and EFQMA, the Deming Prize does not provide a structured framework (Vokurka et al., 2000); rather, ten categories must be addressed: policies; organization; information; standardization; human resources; quality assurance; maintenance; improvement; results; and, future plans.

\subsubsection{The shift from Quality to Excellence}

A major difference between the Deming Prize, MBNQA, and EFQMA is that the majority of firms winning the Deming Prize are industrial/manufacturing firms, while there are a substantial number of services, healthcare institutions, universities, and government agencies being awarded the MBNQA and EFQMA (Sampaio et al., 2012). A possible explanation is the custodianship by the Japanese Union of Scientist and Engineers. This custodianship may also explain why the link between TQM and the Deming Prize remained intact while, for the EFQMA - which started with a strong emphasis on TQM - the concept of TQM became largely replaced by the concept of excellence. Dale et al. (2000) argue that a major driver behind the move from quality and TQM to the term excellence around the year 2000 was the EFQM and certain management consultancies; the first in response to the perceived tarnished image of TQM and the second to address decreasing demand and increasing competition for their services. A similar movement took place in the US. Consequently, Dahlgaard-Park (2011) observes a general loss of attractiveness of the term TQM from the beginning of the 2000s, with TQM being superseded by terms such as Business Excellence, Lean Management, and Six Sigma. In contrast, in Japan, the focus on TQM was maintained: 'Within Japanese business there is a conviction that TQM pays off and considerable belief in, and respect for, what quality can do for the individual, the organization and the government as a whole (Dale et al. 2000, p4)'.

\subsubsection{Criticism}

A first point of criticism is the high number of excellence models and associated awards. Already at the beginning of the 2000s, Swift et al. (2000) observed a veritable boom in the provision of 'quality audits' - that is, audits of organizations' production processes and management systems - without a critical review by academia. Meanwhile, Hermel \& RamisPujol (2003) observed that excellence prizes and quality standards seem to be competing for market share. A second point of criticism is the essential amount of time and effort which needs to be expended. For example, Dale et al. (2000), in the context of the EFQMA, goes so 
far as to argue that taking into consideration the qualification of EFQMA trained assessors and the substantial amount of time and money spent in running for an award raises the concern 'that a - very expensive - game is being played'.

\subsection{The Toyota Production System and Lean Management}

Another management philosophy linked to excellence is Lean Management. For example, Liker (2004, Figure 1-1) argues that the success of Toyota is a direct result of operational excellence. This operational excellence is the outcome of 14 management principles that constitute the Toyota Way, which is the essence of the Toyota Production System that gave rise to Lean Management. These 14 principles can be grouped into 4 categories, with each starting with a P - Toyota's 4Ps: (i) Philosophy (long-term thinking); (ii) Process (eliminate waste); (iii) People \& Partners (respect, challenge, and grow them); and, (iv) Problem solving (continuous improvement and learning). Meanwhile, Womack \& Jones (1996) outline five lean principles: (i) specify value; (ii) identify the value stream; (iii) create flow; (iv) pull value; and, (v) strive for perfection.

The Shingo Model, which underlies the Shingo Prize, is based on ten guiding principles that are grouped into four categories: (i) cultural enablers (lead with humility, respect every individual); (ii) continuous improvement (flow \& pull value, assure quality at the source, focus on process, embrace scientific thinking, seek perfection); (iii) enterprise alignment (create constancy of purpose, think systemically); and (iv) results (create value for the customer). The Shingo Prize of Operational Excellence was founded as the Shingo Prize for Excellence in Manufacturing in 1988 to honor Shigeo Shingo and his contributions to the development of the Toyota Production System.

\subsection{Other Business Excellence Models}

This section briefly introduces other excellence models known from the literature: Tom Peters' business excellence model, G. Kanji's model to business excellence, and S.M. Dahlgaard-Park and J.J. Dahlgaard's 4P Model. Each will be discussed in turn in Section 3.3.1 to 3.3.3, respectively.

\subsubsection{Tom Peters' Business Excellence Model}

Peters \& Waterman (1982) identified design attributes that distinguish excellent companies. According to Dahlgaard-Park \& Dahlgaard (2007), there are eight attributes that can be summarized as: (i) a bias for action; (ii) close to the customer; (iii) autonomy, entrepreneurship and innovation throughout the organization; (iv) productivity through 
people; (v) hands-on, value driven; (vi) business focused; (vii) simple and lean structures; and, (viii) centralized and decentralized organizational structure. According to Dale et al. (2000), there are nine attributes which, in part, significantly differ from the eight attributes from Dahlgaard-Park \& Dahlgaard (2007). While attributes (i) to (iv) correspond to (i) to (iv) above, the remaining attributes are as follows: (v) management commitment through handson involvement; (vi) business focus; (vii) streamlined processes and operations; (viii) teambased work environment which is driven by shared values; and, (ix) process-based culture. Peters \& Austin (1985) later (i.e. after Peters \& Waterman, 1982) came to regard excellence as being the result of four critical success factors: (i) people, who practice; (ii) care of customers; (iii) constant innovation; and (iv) leadership, which binds together the first three factors by using management by wandering around (MBWA) at all levels of the organization (Dahlgaard-Park \& Dahlgaard, 2007). This MBWA is similar to the focus on gemba observed in Lean Management.

\subsubsection{G. Kanji's Model to Business Excellence}

By analyzing TQM, G. Kanji developed the Kanji model in a series of papers (e.g. Kanji, 1996, 1998; Kanji \& Wong, 1999). G. Kanji's model consists of eight core concepts, which can be subdivided into four principles: (i) delight the customer (customer satisfaction, internal customers are real); (ii) management by fact (all work is process, measurement); (iii) people-based management (teamwork, people make quality); and, (iv) continuous improvement (continuous improvement cycle, prevention). In addition, a fifth overarching principle, which pervades all other principles, is leadership.

\subsubsection{Dahlgaard-Park and Dahlgaard's 4Ps Model}

A first detailed account of the 4Ps model is given in Dahlgaard-Park \& Dahlgaard (2007). The authors argue that building excellence into the following 4Ps develops Operational Excellence: (i) people; (ii) partnership; (iii) processes; and, (iv) products. This basic model was later extended in Dahlgaard et al. (2013) by defining a set of four enablers (or critical success factors) which lead to the result, i.e. the product. The enablers are the original first three - people, partnership, and processes - plus leadership, which pervades the other enablers. An interesting aspect is that Lean Management is only seen as part of the process component. 


\subsection{Summary Discussion}

Our review has identified nine major concepts/models related to excellence. These concepts are summarized in Table 4. The following can be observed:

- It appears that all excellence models (or quality awards) share similar criteria that reflect previous work, e.g. Deming's 14 points or the basic tenets of the Toyota Production System.

- Most criteria appear to generally represent best practices. They define what it is that one should be excellent at doing, but not what it means to be excellent in performing/using a certain practice.

[Take in Table 4]

Addressing the first bullet point above is the task of the providers of excellence models. They have to show that their models are unique and are not just competing for market share (Hermel \& Ramis-Pujol, 2003). In the next section, we seek to address the second bullet point by providing a definition of excellence that emerges from the literature. We hope that this contributes to resolving the confusion on what excellence means in practice (Ritchie \& Dale, 2000).

\section{Results - Use and Definition of Excellence}

The term 'excellence' is mostly used as a desired outcome. It is typically assumed that the reader knows what is meant by the term. Less than 1 in every 5 papers from our database presented a definition of the excellence concept that was being used (36 definitions of the term business excellence, 18 definitions of operational excellence, 11 definitions of service excellence, and 14 definitions of other excellence concepts). The remainder of this section will present and discuss the different definitions. The definitions of business excellence are first discussed in Section 4.1. Section 4.2 then focuses on the definitions of operational and service excellence before the definitions of other excellence concepts are discussed in Section 4.3. Finally, a short summary discussion is presented in Section 4.4.

\subsection{The Definition of Business Excellence in the Literature}

The different definitions of business excellence that could be identified from our systematic literature review are summarized in Table 5 in chronological order.

[Take in Table 5] 
A first definition was given by Edgeman (1998): "the overall way of working that results in balanced stakeholder satisfaction so increasing the probability of long term success as a business". By taking a closer look at this definition, we see that it integrates three aspects: action, result, and business success. Business excellence itself is the action conditioned by the other two aspects. A similar view is shared by, e.g. Ritchie \& Dale (2000b), which sees the end goal of business excellence as the adoption of best practices. These best practices are again conditioned by a set of desired results. Another form of definitions defines business excellence in terms of the results achieved (e.g. Kanji, 2002b; Hsu \& Shen, 2005). These two conceptualizations - action conditioned by results and the results - prevail. Exceptions are Sharma \& Talwar (2007), which perceives business excellence as perfection; Burnes \& O'Donnell (2011), which sees mental toughness as a key to (and thus a defining characteristic of) business excellence; and Jayamaha et al. (2011) and Vora (2013), which interpret business excellence as high-scoring on the criteria of business excellence models.

\subsection{The Definition of Operational and Service Excellence in the Literature}

The different definitions of operational and service excellence that could be identified from our systematic literature review are summarized in Table 6 and Table 7, respectively. Again, definitions are presented in chronological order.

\section{[Take in Table 6 \& Table 7]}

Operational excellence is mostly defined as a result - as cost leadership. In general, definitions refer to efficient operations that provide this cost leadership. A quite different aspect of any operation/business is expressed by service excellence - that of effectiveness. Service excellence is largely defined as providing or even exceeding on what is requested by the customer. It appears that operational and service excellence capture two different aspects of any operation/business: efficiency and effectiveness, respectively.

\subsection{The Definition of Other Excellence Concepts in the Literature}

Definitions of six other excellence concepts could be identified from our systematic literature review: leadership excellence, manufacturing excellence, organizational excellence, sustainable enterprise excellence, security excellence, and industrial excellence. The different definitions are summarized in Table 8 .

[Take in Table 8] 
As somewhat expected, leadership excellence refers to excellent leadership. Manufacturing excellence, organizational excellence, and industrial excellence appear to be very similar to business excellence. Meanwhile, sustainable enterprise excellence appears to extend the business excellence concept via a strong environmental component, while security excellence extends business excellence via a data/information security component.

\subsection{Summary Discussion}

A summary of the prevailing definitions of the different excellence concepts identified from our review is given in Table 9. In general, it may be argued that leadership excellence is part of business excellence since leadership is a major criterion of all business excellence models. Meanwhile, business excellence and operational/service excellence appear to capture two aspects of any operation/business: (i) action (or practice) and results; and, (ii) efficiency vs. effectiveness. It is quite surprising that the efficiency/effectiveness divide did not enter the discussion on business excellence while it appears to be the major difference between operational and service excellence. In the next section, we seek to provide a unifying definition of excellence based on the different excellence concepts from the literature.

\section{[Take in Table 9]}

Finally, the above definitions of different excellence concepts emerged from our literature review. When checking the websites of the main excellence model providers, we also encountered the term 'performance excellence', which is defined by the Baldrige award as: "an integrated approach to organizational performance management that results in (1) delivery of ever-improving value to customers and stakeholders, contributing to ongoing organizational success; (2) improvement of your organization's overall effectiveness and capabilities; and (3) learning for the organization and for people in the workforce. https://www.nist.gov/baldrige/self-assessing/baldrige-key-terms\#performance". $\quad$ This definition closely follows definitions given by other authors and is linked to the Baldrige excellence model and its core values.

\section{Discussion of Results - Definition of Business Excellence}

The above review has highlighted a plethora of different concepts linked to excellence. We saw that there are many different excellence models and different excellence types (such as operational, service, and business excellence). This may explain why excellence remains confusing to practitioners (Ritchie \& Dale, 2000; Hermel \& Ramis-Pujol, 2003). 
If we take a closer look at the criteria from the excellence models then we see that it combines the input and output of an organization (or system):

- Input (the action taken) is defined by two dimensions: What? And, how? All parts that constitute an organization represent the what; for example, people, processes, and facilities. Meanwhile, the characteristics of each of these parts represent the how; for example, people could be skilled and possess leadership skills, processes could be standardized and represent one-piece flow, and facilities such as machines could be well maintained.

- Output (results) is defined by two dimensions: What? And, how much? For example, products, delivery time and waste are the what. The how much quantifies the output; for example, to make it comparable with other companies.

If we define 'waste' as system input minus system output, then we can measure operational excellence by the degree of waste in the system - the lower the level of waste, the more excellent the system becomes. Similarly, if we define 'waste' as system output minus what the customer desires, then we can measure service excellence by the degree of waste in the system - and the closer to zero, the more excellent it is. This leads to the following definition of business excellence:

Business excellence combines operational and service excellence. The more efficient (operational excellence) and effective (service excellence) an organization is, the higher the level of business excellence.

This definition does not appear new or radical, and it is actually quite intuitive. All definitions of an ideal organization (system) have necessarily to converge on perfect efficiency and effectiveness; regardless of the management philosophy and in which context the ideal is applied. Excellence is measured and defined in relation to this ideal state. Our definition may also be criticized for being quite general - in the end, how are efficiency and effectiveness measured? We chose this general definition since we do not believe that there is one set of criteria on which a firm has to perform excellently. Criteria are idiosyncratic to each company. Prescribing a certain set of measures is likely to lead to sub-optimization towards the prescribed set of measures/criteria regardless of the adequacy of the measures.

In this sense, criteria or core values of excellence models are very similar to decision categories or areas in manufacturing strategy (see, e.g. Wheelwright, 1984; Leong et al., 1990). As in manufacturing strategy, a second content variable is required: priority/capability, i.e. which are the most important or the first that should be achieved? This is also an 
important point in the next subsection, Section 5.1, which discusses guidance towards excellence. Finally, Section 5.2 explores our second research question, i.e. how can excellence be sustained.

\subsection{Guiding Excellence}

Guiding excellence is the major premise of excellence models. These models outline the input required to achieve excellence. However, at the moment, it appears that the recommendation of most models is to be excellent in all input variables. This is very likely to be counterproductive. Resources are restricted '...trade-offs are inevitable; one system cannot be outstanding enough at meeting all criteria to create competitive advantage' (Skinner 1996, p.6). While there are synergy effects across criteria in terms of performance improvement, in terms of competitive position at least, it appears that trade-offs are inevitable (Sarmiento et al., 2013). This need for trade-offs and its strategic dimension is, in our view, not accurately represented in most excellence models. Moreover, excellence models are reasonably generic, developed for a broad set of firms while the actual manufacturing strategy of each individual firm is likely to be contingent on idiosyncratic company characteristics. The criteria for excellence models can be prescriptive or non-prescriptive. The MBNQA was intentionally designed to be non-prescriptive - the originators did not want to be perceived as telling companies 'how to do it'.

\subsection{How to Sustain Excellence?}

Having an ideal, excellent organization, i.e. an organization with zero waste, which provides what the customer/stakeholder/shareholder wants when they want it, does not necessarily mean doing good business since: (i) there may be other ideal organizations; and (ii) customer behavior may not always be rational. The first is addressed by theory on competitive advantage and will be briefly discussed here. The second is an inherent risk of any human action.

According to Barney (1991, p. 102), a firm has competitive advantage when it implements a value-creating strategy that is not simultaneously implemented by any of its competitors; and it obtains a sustained competitive advantage when competitors are unable to duplicate and/or substitute away the benefits gained from this value-creating strategy. In other words, sustaining excellence requires a unique value-creating resource or bundle of resources and sufficient isolating mechanisms to deter or limit imitation, emulation, or substitution are the key to sustained competitive advantage (Teece, 1986; McEvily et al. 2004; Sirmon et al. 2007). This is partly recognized in definitions of excellence given by the developers of 
excellence models. For example, the EFQMA defines excellent organisations as "organisations that achieve and sustain outstanding levels of performance that meet or exceed the expectations of all their stakeholders" (http://www.efqm.org/the-efqm-excellencemodel). However, in terms of the means and guidance provided, many excellence models appear to overemphasize the creation of (unique) value whilst providing little evidence of the means available for capturing this value. In fact, some excellence models focus on directly transferable best practice, which undermines any attempt to deter or limit imitation.

\section{Conclusions}

Excellence is a term/concept that is widely used in research and practice. For example, in terms of research, there are journals such as Total Quality Management \& Business Excellence and Measuring Business Excellence. In terms of practice, there exist the Shingo Model for operational excellence, the Deming Prize, the Baldrige performance excellence program, the European Foundation for Quality Management Excellence Model, and about 80 other national awards that largely base their framework on the latter two models. However, although there have been many suggested definitions of excellence and the success factors behind excellence, only a few organizations have been able to achieve the goal. It was argued that this is due to confusion surrounding the meaning of excellence in practice. Using a systematic review of the literature, we have identified a plethora of concepts associated with excellence, which may explain this confusion.

In answer to our first research question - How is excellence defined? - we have argued that excellence can be defined in relation to the ideal organization. Business excellence combines operational and service excellence. The more efficient (operational excellence) and effective (service excellence) an organization is, the higher the level of business excellence. Our second research question asked: How can excellence be sustained? Based on our definition, business excellence maximizes the probability of obtaining competitive advantage. However, too strong an orientation on excellence models may negatively affect the competitive advantage of a firm since it overemphasizes the creation of value, leaving the actual capture of value behind. This will be discussed in our concluding subsection on managerial implications and future research.

\subsection{Managerial Implications, Limitations and Further Research}

Excellence models provide standard frameworks for inter- and intra-industry comparison in the context of best practices and benchmarking. However, the key to sustained competitive 
advantage is the development of a unique value-creating resource or bundle of resources and sufficient isolating mechanisms to deter or limit imitation, emulation, or substitution. Managers should keep this in mind and not focus entirely on creating value - they must also expend effort in creating these isolating mechanisms. Similarly, managers have to make trade-off decisions - not all inputs to an organization can be excellent. It is a question of having an appropriate operations strategy and of having an alignment between the inputs, the outputs, and what the customer wants. Exploring this strategic dimension of excellence is also the major future research direction that emerges out of our review. Excellence models emerged to recognize great achievement. Silently, the evaluation criteria of the Awards have been transformed into guiding principles to achieve excellence. But this transformation cannot be direct. Rather, a strategic component considering concepts such as strategic choice, alignment, and competitive advantage has to be added.

Finally, a limitation of our study is that it only takes the perception of the research community into account. This neglects the perspective of the developers/administrators of excellence models and the practitioner users of these models. Exploring this perspective, and potentially contrasting it with the perception of the research community, is a major potential avenue for future case study and survey research.

\section{References}

Abbasi, M., \& Kaviani, M. A. (2016). Operational efficiency-based ranking framework using uncertain DEA methods: An application to the cement industry in Iran. Management Decision, 54(4), 902-928.

Adams, J., \& Graban, M. (2011). CMCD's lab draws on academics, automakers, and therapists to realize its own vision of excellence. Global Business and Organizational Excellence, 30(4), 12-28.

Ahmed, A.H.S.R. (2009). Achieving Egyptian higher education institutions' excellence through the application of the EFQM model: an investigative study. International Journal of Business Excellence, 2(2), 157-178.

Ahn, Y. J., Hyun, S. S., \& Kim, I. (2016). Vivid-Memory Formation Through Experiential Value In The Context Of The International Industrial Exhibition. Journal of Travel \& Tourism Marketing, $1-21$.

Aladwan, S. A., \& Forrester, P. (2016). The leadership criterion: challenges in pursuing excellence in the Jordanian public sector. The TQM Journal, 28(2), 295-316.

Alfnes, E., Dreyer, H., \& Strandhagen, J. O. (2008). The Operations Excellence audit sheet. In Lean Business Systems and Beyond (pp. 129-141). Springer US. 
Antony, J. P., \& Bhattacharyya, S. (2010). Measuring organizational performance and organizational excellence of SMEs-Part 1: A conceptual framework. Measuring Business Excellence, 14(2), 3-11.

Antony, J. P., \& Bhattacharyya, S. (2010b). Measuring organizational performance and organizational excellence of SMEs-Part 2: An empirical study on SMEs in India. Measuring Business Excellence, 14(3), 42-52.

Aras, G., \& Crowther, D. (2010). Sustaining business excellence. Total Quality Management, 21(5), $565-576$

Asif, M., \& Gouthier, M. H. (2014). What service excellence can learn from business excellence models. Total Quality Management \& Business Excellence, 25(5-6), 511-531.

Barney, J. (1991). Firm resources and sustained competitive advantage. Journal of Management, 17 (1), 99-120.

Barua, A., Konana, P., Whinston, A., \& Yin, F. (2001). Measures for e-business value assessment. IT Professional, 3(1), 47-51.

Basu, R. (2004). Six-Sigma to operational excellence: role of tools and techniques. International Journal of Six Sigma and Competitive Advantage, 1(1), 44-64.

Bendoly, E., Rosenzweig, E. D., \& Stratman, J. K. (2009). The efficient use of enterprise information for strategic advantage: A data envelopment analysis. Journal of Operations Management, 27(4), 310-323.

Bilalis, N., Alvizos, E., Tsironis, L., \& van Wassenhove, L. (2007). Benchmarking the competitiveness of industrial sectors: Application in textiles. International Journal of Productivity and Performance Management, 56(7), 603-622.

Bowerman, M. (2002). Theme: Local Government: Isomorphism Without Legitimacy? The Case of the Business Excellence Model in Local Government. Public Money and Management, 22(2), 4752.

Breja, S. K., Banwet, D. K., \& Iyer, K. C. (2010). Role of flexibility in sustaining excellence: case of a TQM company. International Journal of Productivity and Quality Management, 5(3), 333-365.

Breja, S. K., Banwet, D. K., \& Iyer, K. C. (2011). Quality strategy for transformation: a case study. The TQM Journal, 23(1), 5-20.

Breja, S. K., Banwet, D. K., \& Iyer, K. C. (2016). Towards sustainable excellence: strategic analysis of Deming Prize winning companies. The TQM Journal, 28(3), 390-410.

Brumme, H., Simonovich, D., Skinner, W., \& Van Wassenhove, L. N. (2015). The Strategy-Focused Factory in Turbulent Times. Production \& Operations Management, 24(10), 1513-1523.

Bunzel, D., Clegg, S., \& Teal, G. (2002). Disciplining customers at the grand seaside hotel. Journal of Management \& Organization, 8(02), 1-13.

Burnes, B., \& O'Donnell, H. (2011). What can business leaders learn from sport?. Sport, Business and Management: An International Journal, 1(1), 12-27. 
Caruana, A., Pitt, L. F., \& Morris, M. H. (1995). Are there excellent service firms, and do they perform well?. Service Industries Journal, 15(3), 243-256.

Chakravorty, S. S., Atwater, J. B., \& Herbert, J. I. (2008). The Shingo Prize for operational excellence: rewarding world-class practices. International Journal of Business Excellence, 1(4), 418-433.

Choudhury, K. (2013). Service quality and customers' purchase intentions: an empirical study of the Indian banking sector. International Journal of Bank Marketing, 31(7), 529-543.

Cocks, G. (2014). Optimising pathways for an organisational change management programme. The TQM Journal, 26(1), 88-97.

Dahlgaard, J. J., Chen, C. K., Jang, J. Y., Banegas, L. A., \& Dahlgaard-Park, S. M. (2013). Business excellence models: Limitations, reflections and further development. Total Quality Management \& Business Excellence, 24(5-6), 519-538.

Dahlgaard-Park, S. M. (2011). The quality movement: Where are you going?. Total Quality Management \& Business Excellence, 22(5), 493-516.

Dahlgaard-Park, S.M., \& Dahlgaard, J. J. (2007). Excellence-25 years evolution. Journal of Management History, 13(4), 371-393.

Dahlgaard-Park, S. M., Chen, C. K., Jang, J. Y., \& Dahlgaard, J. J. (2013). Diagnosing and prognosticating the quality movement-a review on the 25 years quality literature (1987-2011). Total Quality Management \& Business Excellence, 24(1-2), 1-18.

Dale, B.G., Zairi, M., Van der Wiele, A., Williams, A.R.T. (2000). Quality is dead in Europe - long live excellence - true or false?. Measuring Business Excellence, 4(3),4-10.

Dereli, T., Durmuşoğlu, A., Delibaş, D., \& Avlanmaz, N. (2011). An analysis of the papers published in total quality management \& business excellence from 1995 through 2008. Total Quality Management, 22(3), 373-386.

e Sá, P. M., \& Kanji, G. (2003). Leadership for excellence in the Portuguese municipalities: Critical success factors, measurements and improvement strategies. Total Quality Management \& Business Excellence, 14(2), 131-139.

Edgeman, R. L. (1998). Principle-centered leadership and core value deployment. The TQM Magazine, 10(3), 190-193.

Edgeman, R. (2013). Sustainable Enterprise Excellence: towards a framework for holistic dataanalytics. Corporate Governance, 13(5), 527-540.

Edgeman, R. (2015). Strategic resistance for sustaining enterprise relevance: A paradigm for sustainable enterprise excellence, resilience and robustness. International Journal of Productivity and Performance Management, 64(3), 318-333.

Edgeman, R., \& Eskildsen, J. (2014). Modeling and assessing sustainable enterprise excellence. Business Strategy and the Environment, 23(3), 173-187. 
Edgeman, R. L., Bigio, D., \& Ferleman, T. (2005). Six Sigma and business excellence: Strategic and tactical examination of IT service level management at the office of the chief technology officer of Washington, DC. Quality and Reliability Engineering International, 21(3), 257-273.

Greatbanks, R., \& Tapp, D. (2007). The impact of balanced scorecards in a public sector environment: Empirical evidence from Dunedin City Council, New Zealand. International Journal of Operations \& Production Management, 27(8), 846-873.

Grigg, N., \& Mann, R. (2008). Promoting excellence: An international study into creating awareness of business excellence models. The TQM Journal, 20(3), 233-248.

Hamori, M. (2006). Executive career advancement in career moves across employers: The role of organization-level predictors. The International Journal of Human Resource Management, 17(6), 1129-1151.

Hermel, P., \& Ramis-Pujol, J. (2003). An evolution of excellence: some main trends. The TQM magazine, 15(4), 230-243.

Hitomi, K. (1996). Manufacturing excellence for 21st century production. Technovation, 16(1), 33-41.

Ho, S. K. (1995). Manufacturing excellence in fast-food chains. Total Quality Management, 6(2), 123-134.

Hsu, S. H. (2007). A new business excellence model with business integrity from ancient Confucian thinking. Total Quality Management \& Business Excellence, 18(4), 413-423.

Hsu, S. H., \& Shen, H. P. (2005). Knowledge management and its relationship with TQM. Total Quality Management \& Business Excellence, 16(3), 351-361.

Huang, T. L., \& Liao, S. (2015). A model of acceptance of augmented-reality interactive technology: the moderating role of cognitive innovativeness. Electronic Commerce Research, 15(2), 269-295.

Hughes, A., \& Halsall, D. N. (2002). Comparison of the 14 deadly diseases and the business excellence model. Total Quality Management, 13(2), 255-263.

Jaeger, A., \& Matyas, K. (2016). Transformation of the EFQM approach from business towards operations excellence. Production Engineering, 10(3), 277-291.

Jayamaha, N. P., Grigg, N. P., \& Mann, R. S. (2011). Empirical analysis of the Baldrige Criteria as both an organisational performance measure and a theoretical model. Measuring Business Excellence, 15(1), 20-33.

Vora, M.K. (2013). Business excellence through sustainable change management. The TQM Journal, 25(6), 625-640.

Kamann, D.J.F. (2007). Organizational design in public procurement: a stakeholder approach. Journal of Purchasing and Supply Management, 13(2), 127-136.

Kanji, G. K. (1996). Implementation and pitfalls of total quality management. Total Quality Management, 7(3), 331-343.

Kanji, G. K. (1998). Measurement of business excellence. Total Quality Management, 9(7), 633-643. 
Kanji, G. K. (2002). Business excellence: make it happen. Total Quality Management, 13(8), 11151124.

Kanji, G. K. (2008a). Architecture of business excellence in the public and service sectors. Total Quality Management, 19(4), 399-415.

Kanji, G. K. (2008b). Reality check of six sigma for business excellence. Total Quality Management, 19(6), 575-582.

Kanji, G. K. (2008c). Leadership is prime: how do you measure leadership excellence?. Total Quality Management, 19(4), 417-427.

Kanji, G. K., \& Wong, A. (1999). Business excellence model for supply chain management. Total Quality Management, 10(8), 1147-1168.

Kanji, G. K., \& Wallace, W. (2000). Business excellence through customer satisfaction. Total Quality Management, 11(7), 979-998.

Kanji, G. K., \& e Sá, P. M. (2001). Measuring leadership excellence. Total Quality Management, 12(6), 701-718.

Kanji, G., \& e Sá, P.M. (2007). Performance measurement andbusiness excellence: The reinforcing link for the public sector. Total Quality Management \& Business Excellence, 18(1-2), 49-56.

Karapetrovic, S., \& Willborn, W. (2002). Self-audit of process performance. International Journal of Quality \& Reliability Management, 19(1), 24-45.

Keng, C. J., \& Ting, H. Y. (2009). The acceptance of blogs: using a customer experiential value perspective. Internet Research, 19(5), 479-495.

Keng, C. J., Huang, T. L., Zheng, L. J., \& Hsu, M. K. (2007). Modeling service encounters and customer experiential value in retailing: An empirical investigation of shopping mall customers in Taiwan. International Journal of Service Industry Management, 18(4), 349-367.

Kim, D. Y., Kumar, V., Kumar, U., \& Hwang, Y. H. (2009). A linkage model for the integrated application of intellectual capital management and the EFQM business excellence model: the case of an ISO 9001 certified public R\&D organisation. International Journal of Learning and Intellectual Capital, 6(4), 303-323.

Klefsjö, B., Bergquist, B., \& Garvare, R. (2008). Quality management and business excellence, customers and stakeholders: do we agree on what we are talking about, and does it matter?. The TQM Journal, 20(2), 120-129.

Krippendorff, K. (2003). Content Analysis: An introduction to its methodology. $2^{\text {nd }}$ Ed. Sage Publications.

Leong, G.K., Snyder, D.L., \& Ward, P.T. (1990). Research in the process and content of manufacturing strategy. Omega, 18 (2) 109-122.

Liker, J. K. (2004). The Toyota Way. McGraw-Hill. 
Lo, Q. Q., \& Chai, K. H. (2012). Quantitative analysis of quality management literature published in total quality management and business excellence (1996-2010). Total Quality Management \& Business Excellence, 23(5-6), 629-651.

Lu, D., Betts, A., \& Croom, S. (2011). Re-investigating business excellence: Values, measures and a framework. Total Quality Management \& Business Excellence, 22(12), 1263-1276.

Martin, C., Bulkan, A., \& Klempt, P. (2011). Security excellence from a total quality management approach. Total Quality Management, 22(3), 345-371.

Martín-Castilla, J. I., \& Rodriguez-Ruiz, O. (2008). EFQM model: knowledge governance and competitive advantage. Journal of Intellectual Capital, 9(1), 133-156.

Mathwick, C., Malhotra, N., \& Rigdon, E. (2001). Experiential value: conceptualization, measurement and application in the catalog and Internet shopping environment. Journal of Retailing, 77(1), 39-56.

Mavroidis, V., Toliopoulou, S., \& Agoritsas, C. (2007). A comparative analysis and review of national quality awards in Europe: Development of critical success factors. The TQM Magazine, 19(5), 454-467.

McEvily, S. K., Eisenhardt, K. M., \& Prescott, J. E. (2004). The global acquisition, leverage, and protection of technological competencies. Strategic Management Journal, 25, 713-722.

Mele, C., \& Colurcio, M. (2006). The evolving path of TQM: towards business excellence and stakeholder value. International Journal of Quality \& Reliability Management, 23(5), 464-489.

Metaxas, I. N., \& Koulouriotis, D. E. (2014). A theoretical study of the relation between TQM, assessment and sustainable business excellence. Total Quality Management \& Business Excellence, 25(5-6), 494-510.

Mikalef, P., Pateli, A., Batenburg, R. S., \& Wetering, R. V. D. (2015). Purchasing alignment under multiple contingencies: a configuration theory approach. Industrial Management \& Data Systems, $115(4), 625-645$.

Mohammad, M., Mann, R., Grigg, N., \& Wagner, J.P. (2011). Business Excellence Model: An overarching framework for managing and aligning multiple organizational improvement initiatives. Total Quality Management \& Business Excellence, 22(11), 1213-1236.

Moores, B. (1990). The service excellence experience. Marketing Intelligence \& Planning, 8(6), 1824.

Oakland, J. S., \& Tanner, S. J. (2008). The relationship between business excellence and performance-An empirical study using Kanji's leadership excellence model. Total Quality Management, 19(7-8), 733-749.

Ovanessoff, A., \& Purdy, M. (2011). Global competition 2021: key capabilities for emerging opportunities. Strategy \& Leadership, 39(5), 46-55.

Peters, T.J., \& Waterman, R.H. (1982). In search of excellence: Lessons from America's best-run companies. Harper \& Row: New York. 
Peters, T.J., \& Austin, N. (1985). A Passion for Excellence - The Leadership Difference. Harper Collins Publishers: London.

Rai, A., Patnayakuni, R., \& Seth, N. (2006). Firm performance impacts of digitally enabled supply chain integration capabilities. MIS quarterly, 225-246.

Rebelo, M., Santos, G., \& Silva, R. (2014). Conception of a flexible integrator and lean model for integrated management systems. Total Quality Management \& Business Excellence, 25(5-6), 683701.

Reimann, M., Schilke, O., \& Thomas, J. S. (2010). Toward an understanding of industry commoditization: Its nature and role in evolving marketing competition. International Journal of Research in Marketing, 27(2), 188-197.

Ritchie, L., \& Dale, B. G. (2000). Self-assessment using the business excellence model: A study of practice and process. International Journal of Production Economics, 66(3), 241-254.

Ritchie, L., \& Dale, B. G. (2000b). An analysis of self-assessment practices using the business excellence model. Proceedings of the Institution of Mechanical Engineers, Part B: Journal of Engineering Manufacture, 214, 7, 593-602.

Sampaio, P., Saraiva, P., \& Monteiro, A. (2012). A comparison and usage overview of business excellence models. The TQM Journal, 24(2), 181-200.

Savolainen, T. (2000). Leadership strategies for gaining business excellence through total quality management: a Finnish case study. Total Quality Management, 11(2), 211-226.

Selvarajah, C., \& Meyer, D. (2008). Profiling the Chinese manager: Exploring dimensions that relate to leadership. Leadership \& Organization Development Journal, 29(4), 359-375.

Sharma, A. K., \& Talwar, B. (2007). Evolution of "universal business excellence model" incorporating Vedic philosophy. Measuring Business Excellence, 11(3), 4-20.

Sharma, M., \& Kodali, R. (2008). TQM implementation elements for manufacturing excellence. The TQM Journal, 20(6), 599-621.

Shobeiri, S., Laroche, M., \& Mazaheri, E. (2013). Shaping e-retailer's website personality: The importance of experiential marketing. Journal of Retailing and Consumer Services, 20(1), 102-110.

Shobeiri, S., Mazaheri, E., \& Laroche, M. (2014). Improving customer website involvement through experiential marketing. The Service Industries Journal, 34(11), 885-900.

Sirmon, D. G., Hitt, M. A., \& Ireland RD. (2007). Managing firm resources in dynamic environments to create value: Looking inside the black box. Academy of Management Review, 32, 273-292.

Skinner, W. (1996). Manufacturing Strategy on the 'S' Curve. Production \& Operations Management, 5(1) 3-14.

Stank, T. P., Esper, T. L., Crook, T. R., \& Autry, C. W. (2012). Creating relevant value through demand and supply integration. Journal of Business Logistics, 33(2), 167-172.

Swift, T. A., Humphrey, C., \& Gor, V. (2000). Great expectations?: The dubious financial legacy of quality audits. British Journal of Management, 11(1), 31-45. 
Tallon, P. P. (2007). Does IT pay to focus? An analysis of IT business value under single and multifocused business strategies. The Journal of Strategic Information Systems, 16(3), 278-300.

Tallon, P. P. (2010). A service science perspective on strategic choice, IT, and performance in US banking. Journal of Management Information Systems, 26(4), 219-252.

Talwar, B. (2011). Business excellence models and the path ahead.... The TQM Journal, 23(1), 21-35.

Tambi, A. M. B. A., Ghazali, M. C., \& Yahya, N. B. (2008). The ranking of higher education institutions: A deduction or delusion?. Total Quality Management \& Business Excellence, 19(10), 997-1011.

Teece, D. J. (1986). Profiting from technological innovation. Research Policy, 15, 285-305.

Tranfield, D., Denyer, D., \& Smart, P. (2003). Towards a methodology for developing evidenceinformed management knowledge by means of systematic review. British Journal of Management, 14(3), 207-222.

Vokurka, R. J., Stading, G. L., \& Brazeal, J. (2000). A comparative analysis of national and regional quality awards. Quality Progress, 33(8), 41.

Vrellas, C. G., \& Tsiotras, G. (2015). Quality management in the global brewing industry. International Journal of Quality \& Reliability Management, 32(1), 42-52.

Wheelwright, S.C. (1984). Manufacturing Strategy: Defining the missing link. Strategic Management Journal, 5(1) 77-91.

Wilkinson, G., \& Dale, B. G. (1999). Models of management system standards: a review of the integration issues. International Journal of Management Reviews, 1(3), 279-298.

Zacharias, N. A., Nijssen, E. J., \& Stock, R. M. (2016). Effective configurations of value creation and capture capabilities: Extending Treacy and Wiersema's value disciplines. Journal of Business Research, 69(10), 4121-4131.

Zack, M., McKeen, J., \& Singh, S. (2009). Knowledge management and organizational performance: an exploratory analysis. Journal of Knowledge Management, 13(6), 392-409. 


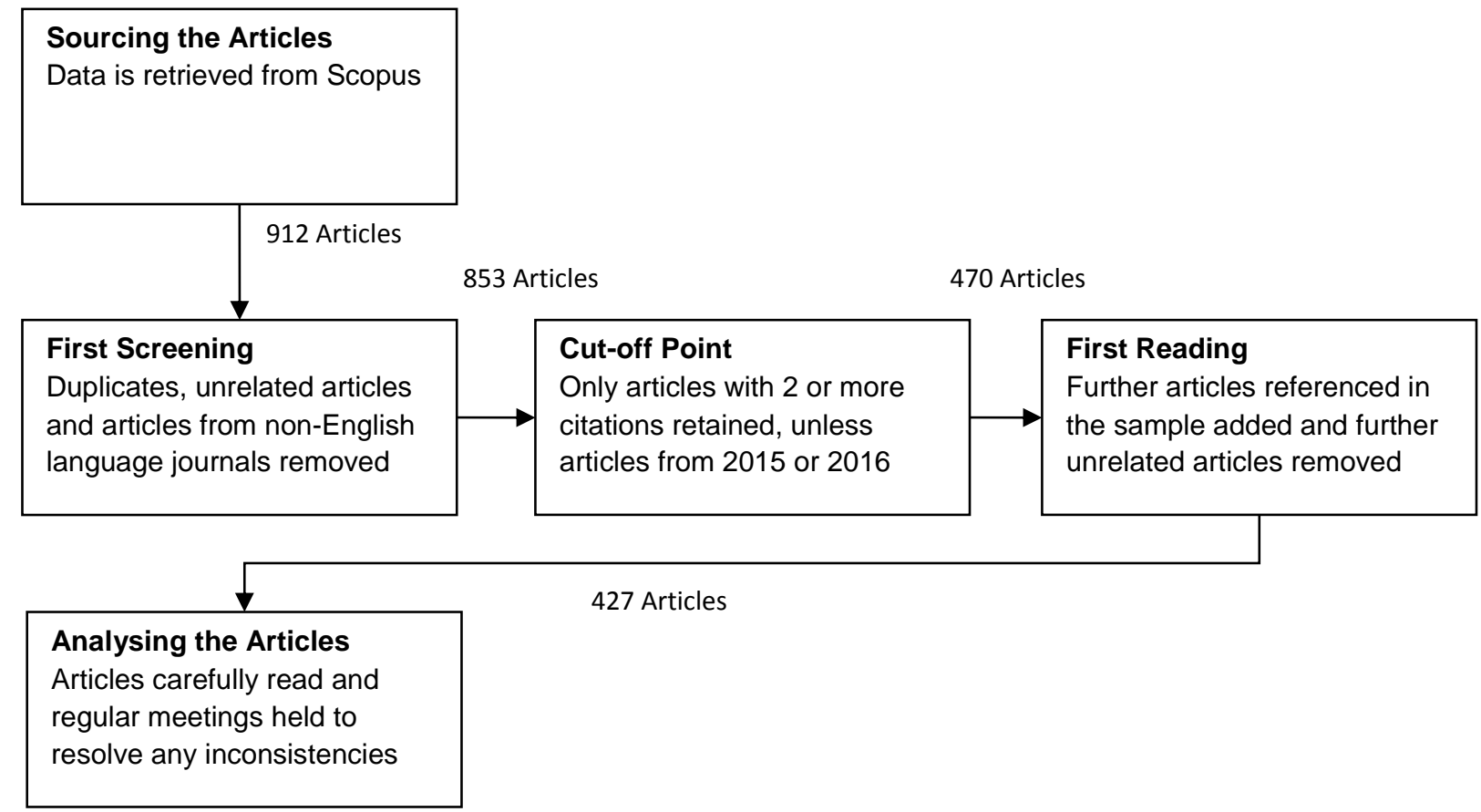

Figure 1: Systematic Review of the Literature-Methodology

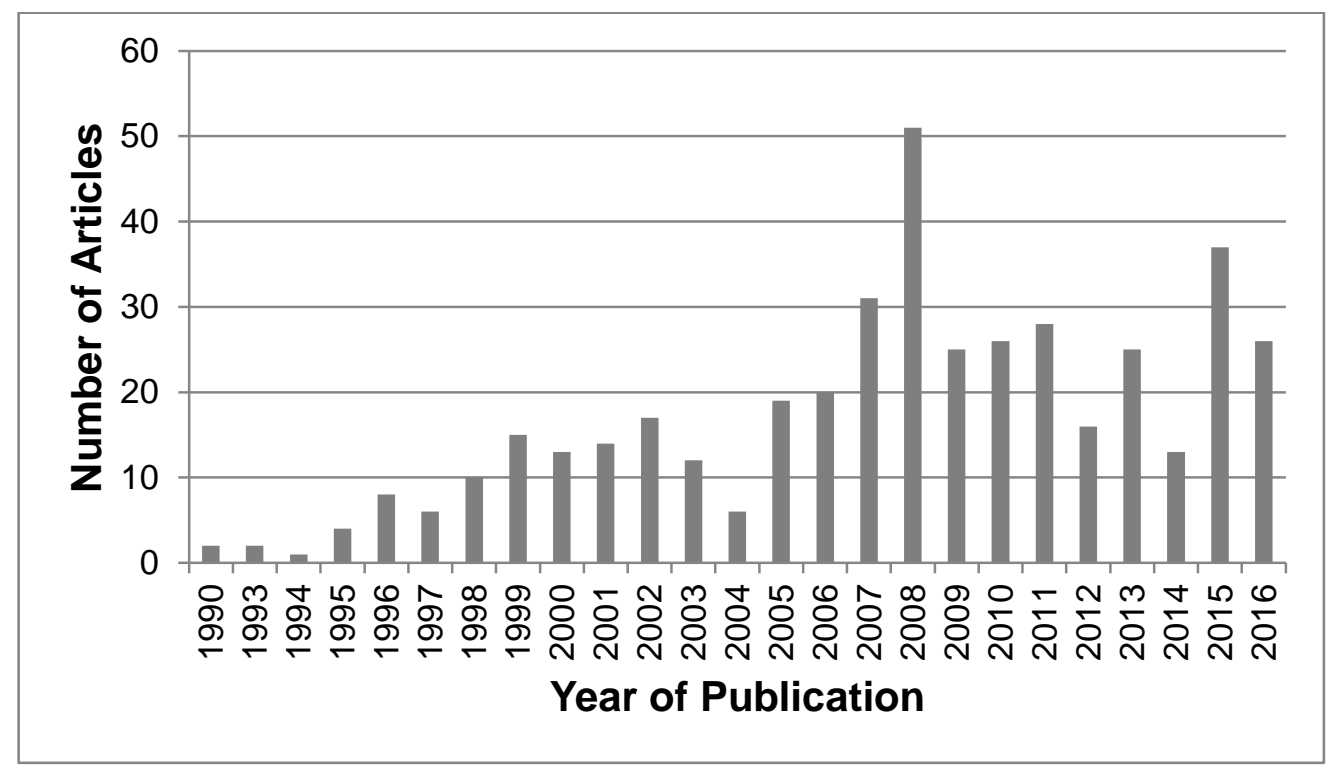

Figure 2: Sample Characteristics - Distribution of Articles per Year 
Table 1: Sample Characteristics - Journals Where Relevant Papers Have Been Published

\begin{tabular}{|c|c|}
\hline Journal & Number of Articles (Percent) \\
\hline Total Quality Management and Business Excellence & $75(17.56 \%)$ \\
\hline Total Quality Management & $28(6.56 \%)$ \\
\hline International Journal of Quality and Reliability Management & $26(6.09 \%)$ \\
\hline TQM Journal & $24(5.62 \%)$ \\
\hline TQM Magazine & $19(4.45 \%)$ \\
\hline International Journal of Business Excellence & $13(3.04 \%)$ \\
\hline Measuring Business Excellence & $12(2.81 \%)$ \\
\hline Benchmarking & $12(2.81 \%)$ \\
\hline International Journal of Productivity and Performance Management & $7(1.64 \%)$ \\
\hline International Journal of Production Economics & $7(1.64 \%)$ \\
\hline Managing Service Quality & $5(1.17 \%)$ \\
\hline International Journal of Operations and Production Management & $4(0.94 \%)$ \\
\hline Journal of Manufacturing Technology Management & $4(0.94 \%)$ \\
\hline Global Business and Organizational Excellence & $4(0.94 \%)$ \\
\hline Supply Chain Management & $4(0.94 \%)$ \\
\hline Journal of Business Research & $3(0.70 \%)$ \\
\hline International Journal of Contemporary Hospitality Management & $3(0.70 \%)$ \\
\hline Journal of Retailing & $3(0.70 \%)$ \\
\hline International Journal of Lean Six Sigma & $3(0.70 \%)$ \\
\hline International Journal of Hospitality Management & $3(0.70 \%)$ \\
\hline Industrial Management and Data Systems & $3(0.70 \%)$ \\
\hline International Journal of Advanced Manufacturing Technology & $3(0.70 \%)$ \\
\hline Service Industries Journal & $3(0.70 \%)$ \\
\hline Journal of Retailing and Consumer Services & $3(0.70 \%)$ \\
\hline Expert Systems with Applications & $3(0.70 \%)$ \\
\hline Production Planning and Control & $3(0.70 \%)$ \\
\hline International Journal of Service Industry Management & $3(0.70 \%)$ \\
\hline International Journal of Technology Management & $3(0.70 \%)$ \\
\hline Cornell Hospitality Quarterly & $3(0.70 \%)$ \\
\hline Business Horizons & $3(0.70 \%)$ \\
\hline Other (two papers per journal) & $42(9.84 \%)$ \\
\hline Other (one paper per journal) & $96(22.48 \%)$ \\
\hline Total & $427(100 \%)$ \\
\hline
\end{tabular}


Table 2: Sample Characteristics - Related Management Concepts

\begin{tabular}{rl}
\hline Related Management Concept & Number of Articles (Percent) \\
\hline TQM & $108(25.29 \%)$ \\
Lean/TPS & $13(3.04 \%)$ \\
ISO 9000 & $8(1.87 \%)$ \\
Six Sigma & $7(1.64 \%)$ \\
Lean Six Sigma & $6(1.41 \%)$ \\
TPM & $4(0.94 \%)$ \\
\hline Other (no specific concept) & $263(61.6 \%)$ \\
Other (two papers) & $8(1.87 \%)$ \\
Other (one paper) & $10(2.34 \%)$ \\
\hline Total & $\mathbf{4 2 7 ( 1 0 0 \% )}$ \\
\hline
\end{tabular}

Table 3: Sample Characteristics - Areas of Application

\begin{aligned} \hline Area of Application & Number of Articles (Percent) \\ \hline Manufacturing & $83(19.44 \%) \\$ None & $73(17.10 \%) \\$ Not clear & $72(16.86 \%) \\$ Services & $68(15.93 \%) \\$ General & $33(7.73 \%) \\$ Manufacturing and Services & $30(7.03 \%) \\$ Higher education & $10(2.34 \%) \\$ Hospitality industry & $9(2.11 \%) \\$ Public sector & $9(2.11 \%) \\$ Healthcare & $8(1.87 \%) \\$ Financial sector/Banking & $6(1.41 \%) \\$ Retailing & $6(1.41 \%) \\$ Construction & $5(1.17 \%) \\$\hline Other (two papers) & $10(2.34 \%) \\$ Other (one paper) & $5(1.17 \%) \\$\hline Total & $427(100 \%) \\$\hline & \end{aligned}


Table 4: Summary of Concepts Related to Excellence

\begin{tabular}{|c|c|c|}
\hline Category & Name & Criteria/Core Values \\
\hline \multirow{3}{*}{$\begin{array}{l}\text { TQM and } \\
\text { Quality } \\
\text { Awards }\end{array}$} & Deming Prize & $\begin{array}{l}\text { policies; organization; information; standardization; human resources; quality } \\
\text { assurance; maintenance; improvement; results; and, future plans }\end{array}$ \\
\hline & MBNQA & $\begin{array}{l}\text { leadership; strategy; customers; measurement, analysis, and knowledge } \\
\text { management; workforce; operations; and, results }\end{array}$ \\
\hline & EFQMA & $\begin{array}{l}\text { enablers: leadership; people; management; policy and strategy; partnerships } \\
\text { and resources; and, processes } \\
\text { results: people results; customer results; society results; and, key performance } \\
\text { results }\end{array}$ \\
\hline \multirow{3}{*}{$\begin{array}{l}\text { TPS and } \\
\text { Lean }\end{array}$} & Liker's 4P & $\begin{array}{l}\text { philosophy (long-term thinking); process (eliminate waste); people \& partners } \\
\text { (respect, challenge and grow them); and, problem solving (continuous } \\
\text { improvement and learning) }\end{array}$ \\
\hline & $\begin{array}{r}\text { Womack \& } \\
\text { Jones (1996) }\end{array}$ & $\begin{array}{l}\text { specify value; identify the value stream; create flow; pull value; and, strive for } \\
\text { perfection }\end{array}$ \\
\hline & Shingo Prize & $\begin{array}{l}\text { cultural enablers (lead with humility, respect every individual); continuous } \\
\text { improvement (flow \& pull value, assure quality at the source, focus on process, } \\
\text { embrace scientific thinking, seek perfection); enterprise alignment (create } \\
\text { constancy of purpose, think systemically); and, results (create value for the } \\
\text { customer) }\end{array}$ \\
\hline \multirow{3}{*}{ Others } & $\begin{array}{r}\text { Tom Peters' } \\
\text { Model }\end{array}$ & people, who practice; care of customers; constant innovation; and, leadership \\
\hline & G. Kanji's Model & $\begin{array}{l}\text { delight the customer (customer satisfaction, internal customers are real); } \\
\text { management by fact (all work is process, measurement); people-based } \\
\text { management (teamwork, people make quality); and, continuous improvement } \\
\text { (continuous improvement cycle, prevention) }\end{array}$ \\
\hline & $\begin{array}{r}\text { Dahlgaard-Park } \\
\text { \& Dahlgaard's } \\
4 \mathrm{P}\end{array}$ & $\begin{array}{l}\text { people; partnership; processes; and, products (plus leadership in Dahlgaard et } \\
\text { al. (2013)) }\end{array}$ \\
\hline
\end{tabular}




\section{Table 5: Definitions of Business Excellence from the Literature}

Edgeman (1998, p.190)

Kanji \& Wong (1999, p.1147)

Wilkinson \& Dale (1999, Table 2, p.296)

Savolainen (2000, p.212)

Ritchie \& Dale (2000, p.595)

Kanji (2002, p.1115)

Karapetrovic \& Willborn

(2002, p.24)

Boys et al. (2005, p.4)

Edgeman et al. (2005, p.260)

Hsu \& Chen (2005, p.358)

Mele \& Colurcio $(2006$ p.481)

Kanji \& e Sa (2007, p.49)

Sharma \& Talwar $(2007$ p.5)

Hsu (2007, p.417)
Ian Raisbeck, chairman of the European Foundation for Quality Management, referred to business excellence as "the overall way of working that results in balanced stakeholder satisfaction so increasing the probability of long term success as a business." That "overall way of working" is identified by Dahlgaard et al. (1997) as "excellency in TQM, creativity and learning".

simultaneous measurement of customers', employers' and shareholders' delights within an organization to provide overall business success.

improved performance in all areas

achieving a better business performance

BE is a long term process, the end goal being the adoption of best practices to foster a culture that would support the business's needs and objectives, to achieve best in class status and to move forward by continuously achieving high performance levels

Business Excellence has been defined by the author as 'a means of measuring customer's, employer's, and shareholder's (stakeholders) satisfaction simultaneously within an organization in order to obtain a comprehensive evaluation of the organizational performance

business excellence is taking over the narrow definition of meeting customer specification in quality

To be successful, organizations must now prove themselves indispensable to their customers, attuned to their employees' needs, willing to partner with their suppliers, and considerate of the social, environmental, and safety outcomes of their performance. These new and expanded objectives of business operations have been combined under the umbrella term, business excellence (BE).

Business Excellence is an overall way of working that balances stakeholder interests and increases the likelihood of sustainable competitive advantage and hence long-term organizational success through operational, customer related, financial, and marketplace performance excellence.

excellence is achieving results that delight all the organization's stakeholders (this includes employees, customers, suppliers, society in general and those with financial interests in the organization)

superiority achieved by the enterprise towards the market where it operates. In other words the achievement of a position of excellence is linked to the enterprise capacities to obtain superior results over competitors on behalf of customers, of the enterprise itself and of the other stakeholders

the simultaneous satisfaction of key organisational stakeholders

Excellence means perfection. Excellence lies in beauty of flowers. As one approaches perfection in one's work, one approaches excellence. Man can attain excellence or perfection through his/her actions.

The critical success factors are leadership, delight the customer, focus on fundamentals, people-based management and continuous 
improvement in order to achieve the best result (i.e. business excellence)

Greatbanks \& Tapp $(2007$, p.863)

Selvarajah \& Meyer (2008, p.359)

Kanji (2008b, p.577)

Klefsjö et al. (2008, p.126)

Tambi et al. (2008, p.1003)

Martin-Castilla \& Rodriguez Ruiz (2008, p.136)

Kanji (2008a, p.400)

Ahmed (2009, p.159)

Breja et al. (2010, p.337)

Aras \& Crowther (2010, p.565)

Mohammad et al. (2011, p.1214)

Dahlgaard-Park (2011, p.510) extension of the AMP target, and is considered to represent a level of individual and team performance beyond that naturally achievable through delivering the AMP (AMP = Activity Management Plan)

The term "excellence" is used here in its standard definition of surpassing others in accomplishment or achievement

To achieve high customer satisfaction levels (delight the customer); the organisation must continually improve all aspects of its operation (continuous improvement). This can be achieved through its leadership making decisions on the objective evidence of what is actually happening (management by fact) and by involving all employees in quality improvement activities (people based management). The ultimate outcome of this vision will be the achievement of Business Excellence.

In our view, business excellence could be an appropriate term to define "excellence in business". Business excellence could be achieved partly by combining quality excellence with excellence in all other aspects of a business, such as finance, human resources, logistics and organizational impact on society and nature.

Business or organisational excellence, within the context of TQM, may be defined as an outstanding practice in managing the organisation and achieving results based on fundamental TQM principles.

excellence is an outstanding practice in managing the organisation and achieving results

Hence, to fulfil the vision and achieve high customer satisfaction levels (Delight the Customer), the organisation must improve continually all aspects of its operation (Continuous Improvement); this can be achieved through leadership making decisions on objective evidence of what is actually happening (Management by Fact) and by involving all employees in quality improvement activities (People-based Management). The ultimate outcome will be Business Excellence.

Hence, excellence is simply viewed as an outstanding performance which comes from the simultaneous implementation of a set of qualityrelated principles and practices, whereas an organisation must balance the needs of its several stakeholders, such as customers, suppliers, employees, government and the society as a whole.

Continual achievement of all round business goals and targets as enshrined in company vision, for realisation of the mission, made possible through focused efforts (measured, for example, in balanced scorecard format), for satisfaction of all business stakeholders."

In this paper we argue that business excellence (as described by Peters \& Waterman, 1982) is the state to which all business can, and should, aspire. It is important to state at this point exactly what we mean by excellence. For us it has four facets: profitability, sustainability, corporate reputation and good governance.

BE can be defined as 'Excellence in strategies, business practices, and stakeholder-related performance results that have been validated by assessments using proven business excellence models'

This change in attitudes is also reflected in the EFQM definition of Business Excellence presented by lan Raisbeck at the 2nd World Congress on Total Quality Management in Sheffield, UK, June 1997: 'Business Excellence is the overall way of working that result in balanced stakeholder (customers, employees, society, stakeholders) satisfaction so increasing the probability of long term success as a business'. 
Breja et al. (2011, p.7)

Burnes \& O’Donnell (2011, p.14)

Jayamaha et al. (2011, p.23)

Vora (2013, p.626)

Rebelo et al. (2013, p.694)

Cocks (2014, p. 89)

Metaxas \& Koulouriotis (2013, p.1)

Vrellas \& Tsiotras $(2015$ p.45)

Edgeman (2015, p.320)

Breja et al. (2016, p.391)
Continual achievement of all round business goals and targets as enshrined in company vision, for realisation of the mission, made possible through focused efforts [measured, for example, in balanced scorecard format], for satisfaction of all business stakeholders.

But the real key to excellence in both sports and business is not the ability to swim fast or do quantitative analyses quickly in your

head; rather, it is mental toughness. Elite performers in both arenas thrive on pressure; they excel when the heat is turned up. Their rise to the top is the result of very careful planning - of setting and hitting hundreds of small goals. Elite performers use competition to hone their skills, and they reinvent themselves continually to stay ahead of the pack.

Considering the fact that the overall BE score given to an organisation is treated as the sum of the seven category scores (nine category scores in the case of EFQM Excellence Model) and that category scores themselves are sums of their corresponding item scores, it make sense to conceptualise the categories (constructs) as if they belong to a higher order construct (or concept), which may be called "Business Excellence". business excellence is achieved by addressing seven categories of the Baldrige Performance Excellence Program. Each of these categories requires thorough assessment of current processes and systems to identify strengths and areas for improvement.

Quality has always been an imperative for top management, and its management assumed as being the ultimate objective - business excellence through the most favourable quality of the supplied products, services and systems, namely in terms of utility, foreseen life period, cost, reactivity on the delivery times, brand and trustworthiness image, capable of responding to two fundamental challenges: The continual satisfaction of the clients, as well as of the people who produce and/or sell the product, promoting the continuous improvement, the environment protection, as well as, the occupational health and safety of all employees.

The process then involves choosing a recognised framework that defines the "Where" (desired future state). In this paper we define this state as "excellence" and then benchmark the organisational characteristics against that framework.

'Excellent organizations achieve and sustain superior levels of performance that meet or exceed the expectations of all their stakeholders'

The lean vision of business excellence according to Kobayashi (1990) is described as: "The entire factory has become a single production line with zero internal storage. The factory uses the quick transition technology and runs a fully mixed production schedule, resulting in complete flexibility."

If sustainability connotes survival, then excellence is the capacity of the enterprise to both strive and thrive across an array of critical performance domains, where performance is comprised of both results and impact.

Excellence is about strategies and world-class performance. It is defined as "outstanding practice in managing the organisation and achieving results" (EFQM, 2010/2014).; The still-evolving concept of excellence is now seen as achievement and sustenance of outstanding performance and satisfaction of all stakeholders (EFQM, 2010/2014); earlier definition of EFQM (2010/2014) had emphasised on "outstanding practice in managing the organisation". 


\title{
Table 6: Definitions of Operational Excellence from the Literature
}

\author{
Barua et al. (2001, p.48) \\ The operational excellence measures are metrics of a company's performance in its daily operations. \\ Basu (2004, p.56) \\ Operational Excellence $(\mathrm{OE})$ is a broader programme of improving and sustaining business performance in which quality management is \\ embedded. \\ Hamori (2006, p.1136 \\ Perceived operational excellence uses the scores from Fortune magazine's 'America's most admired' and 'Global most admired' rankings. The \\ Fortune rankings rate the ten companies with the highest revenues in 58 industries based on eight criteria: innovation, financial soundness, \\ employee talent, use of corporate assets, long-term investment value, social responsibility, quality of management, and quality of products and \\ services. ) \\ Rai et al. (2006, Table 1 \\ The degree to which a focal firm is better than its competitors in its responsiveness and generation of productivity improvements. \\ p.229) \\ Kamann (2007, p.131) \\ Operational excellence is described as "providing customers with reliable products or services at competitive prices and delivered with minimal \\ difficulty and inconvenience" \\ Tallon (2007, p.285) \\ and more importantly map to Porter's typology as follows: low-cost leadership (operational excellence), niche (customer intimacy), and \\ differentiation (product leadership). As noted by Treacy and Wiersema (1995), "operationally excellent companies deliver a combination of quality, \\ price, and ease of purchase . . . they are not product or service innovators, nor do they cultivate one-to-one relationships with their customers. \\ They execute extraordinarily well, and their proposition to customers is guaranteed low price and/or hassle-free service" \\ Chakravorty et al. $(2008$ \\ p.420) \\ Alfnes et al. (2008, p.130) \\ outstanding achievements in manufacturing or service processes and productivity improvements, quality enhancements and customer service \\ The lean vision of operation excellence can be described by the following quotation from Kobayashi [5]. "In the level five factory .... the entire \\ factory has become a single line with zero internal inventory. The plant uses quick changeover technology and runs a fully mixed production \\ schedule, leading to ultimate adaptability". \\ Zack et al. (2009, p.397) \\ Operational excellence represents competition based on efficient internal operations. \\ Bendoly et al. (2009, \\ p.311) \\ strive for cost effective, rapid, and reliable fulfilment of order requirements \\ Reimann et al. $(2010$ \\ p.191) \\ Tallon $(2010$, p.223) \\ Adams \& Graban $(2011$ \\ The value discipline of operational excellence aims to achieve efficiency and cost reduction in operations. \\ low cost, reliability, accuracy, and availability \\ Patient-Focused Operational Excellence: To be nationally recognized for excellence in laboratory medicine, combining the latest in innovation with \\ efficiency and quality testing in a customer-focused environment.
}


Ovanessoff \& Purdy

(2011, p.49)

Mikalef et al. (2015,

p.628)

Brumme et al. (2015,

Figure 1 p.1515)

Zacharias et al. (2016,

p.2)

Jaeger \& Matyas $(2016$ p.280)
First and foremost, operationally excellent companies stay focused on their "competitive essence" - what they do better than anyone else to win in the market

Operational excellence companies focus on delivering products/services to companies at competitive prices and with minimal inconvenience. Hence, the focus is on reducing overhead costs, reduce transaction and other "friction costs", and optimize business processes across functional, and organizational boundaries.

good cost, speed and reliability

Each strategy offers unique value to customers: Product leadership provides the most advanced technological solution, operational excellence ensures adequate solutions at the lowest cost, and customer intimacy delivers the most customized solution (Treacy \& Wiersema, 1995). (p.1) Operational excellence describes firms that are industry leaders in terms of price and convenience, because they minimize internal cost, such as by eliminating unnecessary production steps or optimizing business processes

The philosophy of operations excellence is a management approach based on the continuous pursuit of creating a superordinated, agile system as a setting lever aimed at the maximization of the operations ability to identify and provide the adequate and optimal setting of enablers that are brought into alignment down and across the business strategy to gain sustainable, customer-driven results at the process level over the entire value chain. In the setting of enablers, particularly but not only intangible criteria such as culture, strategy, development, and empowerment are considered. 
Table 7: Definitions of Service Excellence from the Literature

\begin{abstract}
Moores (1990, p.18)
Mathwick et al. (2001 p.42)

Bunzel et al. (2002, p.5)

Keng et al. (2007, p.353)

Keng \& Ting $(2009$, p.482)

Shobeiri et al. (2013,

p.103)

Choudhury (2013, p.529)

Shobeiri et al. (2014,

p.888)

Asif \& Gouthier (2013,

p.511)

Huang \& Liao (2015,

p.274)

Ahn et al. (2016, p.5)

outstanding level of customer service

Service excellence reflects an inherently reactive response in which the consumer comes to admire a marketing entity for its capacity to serve as a means to a self-oriented end

The striving for service excellence that is seen by the hotel's management as the road to business success presupposes the creation of a match between customers' expectations and the service provided by staff

value-added services that exceed ordinary expectations

generalised consumer appreciation of a service provider who demonstrates expertise and offers a reliable service performance. It is associated with whether service providers provide customers with promised services

Service excellence refers to the degree to which a firm performs ideally and serves as a standard for quality judgments.

Performing the service dependably and accurately is the heart of service marketing excellence

Service excellence is reflected in the level to which a firm could serve as an ideal standard for quality, as well as the degree to which it delivers on its promises by showing expertise

Service excellence means providing services that both exceed customers' expectations and delight them

Service excellence, through professional evaluations and performance outcomes, also indicates consumers' appreciation of a service provider's delivery on its promise [85]. This kind of value can be acquired through the consumer's appraisal and evaluation of services or products [46].

Service excellence refers to the extent to which a service provider delivers services ideally and demonstrates service promises and expertise (Mathwick et al., 2001). Service excellence is created when consumers appreciate products and services, and reflects consumers' reactive and extrinsic responses to service quality.
\end{abstract}




\begin{tabular}{|c|c|c|}
\hline \multirow[t]{3}{*}{$\begin{array}{l}\text { leadership } \\
\text { excellence }\end{array}$} & $\begin{array}{l}\text { Kanji \& e Sa } \\
(2001, \text { p.709) }\end{array}$ & $\begin{array}{l}\text { Leadership excellence is, thus, the result of an outstanding performance of leaders in all these key areas, which, as the definition of } \\
\text { critical success factors (see Leidecker \& Bruno, } 1984 ; \text { Rockart, 1982) suggests, have the greatest impact on the competitive success of } \\
\text { an organization }\end{array}$ \\
\hline & $\begin{array}{l}\text { e Sa \& Kanji } \\
(2003, \text { p.134) }\end{array}$ & $\begin{array}{l}\text { Leadership Excellence is, thus, the result of an outstanding performance of leaders in all these key areas. The Leadership Excellence } \\
\text { Index (LEI) will reflect, in quantitative terms, and through a single and integrated measure, the simultaneous performance of leaders in } \\
\text { the roles of establishing and sharing the values, developing and communicating the vision, defining the mission, selecting and } \\
\text { implementing a strategy, and managing other operational key issues. }\end{array}$ \\
\hline & $\begin{array}{l}\text { Kanji (2008c, } \\
\text { p.422) }\end{array}$ & $\begin{array}{l}\text { Leadership Excellence is thus the result of an outstanding performance of leaders in all these and other key issues, which, as the } \\
\text { definition of critical success factors suggests, have the greatest impact on the competitive success of an organisation. }\end{array}$ \\
\hline \multirow[t]{3}{*}{$\begin{array}{l}\text { manufacturing } \\
\text { excellence }\end{array}$} & $\begin{array}{l}\text { Ho }(1995, \\
\text { p.124) }\end{array}$ & They can be simply regarded as world-class work practices. \\
\hline & $\begin{array}{l}\text { Hitomi }(1996, \\
\text { p.34) }\end{array}$ & $\begin{array}{l}\text { Manufacturing excellence' is now proposed as a keyword expressing the enhancement of the suitability of goods production for pursuing } \\
\text { human happiness, while being rid of excess production, deindustrialization, '3K' and earth-destructive operations. }\end{array}$ \\
\hline & $\begin{array}{l}\text { Sharma \& } \\
\text { Kodali }(2008 \\
\text { p.600) }\end{array}$ & $\begin{array}{l}\text { The concept of manufacturing excellence is considered as a path to be the best manufacturer. It refers to the ultimate goal of achieving } \\
\text { best manufacturing capabilities or best-in-class performance. }\end{array}$ \\
\hline \multirow[t]{4}{*}{$\begin{array}{l}\text { organizational } \\
\text { excellence }\end{array}$} & $\begin{array}{l}\text { Antony \& } \\
\text { Bhattacharyya } \\
(2010, \text { p.3) }\end{array}$ & $\begin{array}{l}\text { Excellence is redefined as the ability or capacity of one performance variable to affect or influence the other performance variables in an } \\
\text { organization. }\end{array}$ \\
\hline & $\begin{array}{l}\text { Antony \& } \\
\text { Bhattacharyya } \\
(2010 b, \text { p.43) }\end{array}$ & $\begin{array}{l}\text { organizational excellence is defined as outstanding practice in managing organizations and delivering values to customers and other } \\
\text { stakeholders }\end{array}$ \\
\hline & $\begin{array}{l}\text { Abbasi \& } \\
\text { Kaviani (2016, } \\
\text { p.902) }\end{array}$ & $\begin{array}{l}\text { Organizations performance excellence is not achievable unless they go toward optimal operations performance which leads to gain } \\
\text { effective operations strategy. }\end{array}$ \\
\hline & $\begin{array}{l}\text { Aladwan \& } \\
\text { Forrester } \\
\text { (2016, p.296) }\end{array}$ & $\begin{array}{l}\text { Most dictionary definitions consider it as relating to "high quality". American dictionaries have referred to excellence as having a variety } \\
\text { of meaning related to achievement, perfection, greatness and supremacy, as well as quality. The EFQM (2014) definition of } \\
\text { organisational excellence is best practice in organisational management in order to achieve results for an institution. There are a number } \\
\text { of elements that form the focus of organisational excellence, according to the European EFQM model, which are: continuous learning, } \\
\text { innovation and improvement; goal clarity; a focus on the customer; leadership; an orientation towards results; development of human } \\
\text { resources; social responsibility; management through facts and processes; and development of partnership. In the context of Jordan, } \\
\text { organisational excellence can be considered as referring to the achievement and maintenance of superior performance levels that equal } \\
\text { and exceed stakeholder expectations and needs }\end{array}$ \\
\hline
\end{tabular}




\begin{tabular}{lll}
\hline $\begin{array}{l}\text { sustainable } \\
\text { enterprise } \\
\text { excellence }\end{array}$ & $\begin{array}{l}\text { Edgeman } \\
(2013, \text { p. 528) }\end{array}$ & $\begin{array}{l}\text { Sustainable Enterprise Excellence balances the complementary and competing interests of key stakeholder segments, including society } \\
\text { and the natural environment and increases the likelihood of superior and sustainable competitive positioning and hence long-term } \\
\text { enterprise success that is defined by high-level organizational resilience and robustness and by continuously relevant and responsible } \\
\text { governance, strategy and actions that produce superior results. } \\
\text { Sustainable enterprise excellence results as a consequence of balancing both the competing and complementary interests of key } \\
\text { stakeholder segments, including society and the natural environment, to increase the likelihood of superior and sustainable competitive } \\
\text { positioning and hence long-term enterprise success. This is accomplished through an integrated approach to organizational design and } \\
\text { function emphasizing superior performance with respect to innovation, business intelligence and analytics, operational and supply chain, } \\
\text { customer-related, human capital, financial, marketplace, societal, and environmental domains. }\end{array}$ \\
\hline $\begin{array}{l}\text { Eskildsen } \\
(2014, \text { p.176) }\end{array}$ & $\begin{array}{l}\text { Martin et al. } \\
\text { (2011, p.356) }\end{array}$ & $\begin{array}{l}\text { Wenpose that security excellence is an extension of business excellence by blending the existing requirements of a business } \\
\text { (whether being financial, legal or ethical domains) with the necessary security mechanisms to protect critical business information, } \\
\text { resources and operations. }\end{array}$ \\
\hline $\begin{array}{l}\text { security excellence } \\
\text { industrial }\end{array}$ & $\begin{array}{l}\text { Bilalis et al. } \\
\text { (2007, p.605) }\end{array}$ & $\begin{array}{l}\text { the purpose of IE is to identify what it is that an industrial firm needs to do well, in order to perform at an excellent level in a sustainable } \\
\text { manner }\end{array}$ \\
\hline
\end{tabular}


Table 9: Summary: Definitions of Excellence from the Literature

\begin{tabular}{r|l}
\hline Business Excellence & Either an action conditioned by excellent results or excellent results \\
Operational Excellence & Cost leadership; efficiency \\
Service Excellence & Provision of what the customer wants (or even more); effectiveness \\
Other excellence concepts & $\begin{array}{l}\text { Leadership excellence refers to excellence in leadership, all other excellence } \\
\text { types reflect or extend business excellence }\end{array}$ \\
\hline
\end{tabular}

